Abstracta Iranica Iranica

Revue bibliographique pour le domaine irano-aryen

Volume 28 | 2007

Comptes rendus des publications de 2005

\title{
Reading Chubak. Costa Mesa, Mazda Publishers, 2005, 209 p.
}

\section{Ève Feuillebois-Piérunek}

\section{(2) OpenEdition}

1 Journals

\section{Édition électronique}

URL : http://journals.openedition.org/abstractairanica/21491

DOI : 10.4000/abstractairanica.21491

ISSN : 1961-960X

Éditeur :

CNRS (UMR 7528 Mondes iraniens et indiens), Éditions de l'IFRI

Édition imprimée

Date de publication : 15 mai 2007

ISSN : 0240-8910

Référence électronique

Ève Feuillebois-Piérunek, "Reading Chubak. Costa Mesa, Mazda Publishers, 2005, 209 p. », Abstracta Iranica [En ligne], Volume 28 | 2007, document 366, mis en ligne le 18 septembre 2007, consulté le 25 septembre 2020. URL : http://journals.openedition.org/abstractairanica/21491 ; DOI : https://doi.org/ 10.4000/abstractairanica.21491

Ce document a été généré automatiquement le 25 septembre 2020.

Tous droits réservés 


\title{
Reading Chubak. Costa Mesa, Mazda Publishers, 2005, 209 p.
}

\author{
Ève Feuillebois-Piérunek
}

1 Čūbak fut un pionnier de la prose moderne persane, il révolutionna les usages de la langue et la narratologie iranienne, et influença profondément les générations suivantes.

2 Ghanoonparvar s'efforce de présenter les différentes étapes de la création littéraire de cet auteur. Les récits de Heymešabbāzī (1945) décrivent, avec une certaine compassion mais sans angélisme, des personnages misérables et opprimés. Dans les œuvres suivantes, Antarī ke lūtīyaš morde būd (1949), Tangsīr (1963), Rūz-e avval-e qabr (1965), les descriptions de la misère matérielle et de la torture psychologique se teintent de critique sociale et font appel à des concepts plus abstraits: liberté, fatalisme, superstition, misère morale. Enfin Sang-e șabūr (1966) marque un tournant dans l'œuvre de Čūbak : le livre reste un miroir de la société iranienne la plus modeste, mais utilise l'introspection et dépeint des héros incertains face à la vie et à un monde chaotique et décadent.

3 Ce petit livre constitue une bonne introduction à l'œuvre de Čūbak, même si son approche est plus descriptive qu'analytique. Dans la conclusion, l'A. règle ses comptes avec Čūbak en déballant les conflits mesquins qui les ont opposés, propos ici parfaitement déplacés.

\section{INDEX}

Thèmes : 11.1.2. Littérature persane moderne 
AUTEURS

ÈVE FEUILLEBOIS-PIÉRUNEK

Sorbonne Nouvelle - Paris III 